\title{
A HARIS [Crex crex (LINNAEUS, 1758)] BIOAKUSZTIKAI VIZSGÁLATA A HANSÁGBAN
}

\author{
Winkler Dániel ${ }^{1}$, Bender Ferenc ${ }^{2}$ \& Németh Tamás Márton ${ }^{1}$ \\ ${ }^{1}$ Nyugat-Magyarországi Egyetem, Vadgazdálkodási és Gerinces Állattani Intézet \\ University of West Hungary, Institute of Wildlife Management \\ H-9400 Sopron, Ady Endre str. 5., Hungary \\ e-mail: winkler.daniel@emk.nyme.hu; tomanemeth@gmail.com \\ 2 Örségi Nemzeti Park Igazgatóság, Örség National Park Directorate \\ H-9941 Öriszentpéter, Siskaszer 26/A, Hungary
}

\begin{abstract}
WinkLeR, D., BENDER, F. \& NÉMETH, T.M.: BioACOUSTICAL STUDY OF THE CORNCRAKE [Crex crex (LinNAeus, 1758)] IN THE HANSÁG. Hungarian Small Game Bulletin 12: 135-149. http://dx.doi.org/10.17243/mavk.2014.135 The aim of this research was to determine the Corncrake (Crex crex) population in the Urhanyi Meadow (North Hanság) based on the vocal individuality of the males. Recordings were made three times (30 April, 14 May, 29 May) during the breeding season of 2010. The number of detected Corncrake males were 3, 8 and 9, respectively. For individual recognition of Corncrake males, bioacoustic methods were used. A total of 15 timeand frequency-based variables were measured and were subjected to canonical discriminant function analysis. Eucidean distances between the obtained discrimunant function scores were measured so as to determine the probability of alikeness. A total of 3 birds were re-identified with high probability in different survey dates. Based on the analyses, a total of 17 different birds were found in the study area.
\end{abstract}

KULCSZAVAK: haris, állománybecslés, bioakusztika, egyedi hangadás

KEY WORDS: Corncrake, bioacustics, population estimates, vocal individuality

\section{BEVEZETÉS}

A haris (Crex crex LinNAEUS, 1758) hazánk egyik rejtett életmódot élö fészkelő madara. Jelenlétét legtöbbször csak a hímek jellegzetes ,recsegő” hangja árulja el. A haris az üde láprétek, magaskórósok fészkelője (HORVÁTH, 2000), aktuális költőállománya az élőhely vízellátottságának függvényében erősen ingadozik (SZÉP, 1991; NÉMETH 2013). Hazai állományát 500-1200 párra becsülik (MME NOMENCLATOR BIZOTTSÁG, 2008). Állománya a Hanságban 2005 és 2009 között 18 és 31 pár között változott (TATAI, 2009).

Egy adott terület haris állomány felmérése legegyszerübben az éneklő hímek számolásával történhet. Ez a más madárfajok esetében is gyakran alkalmazott módszer azonban magában hordozza a duplán számolás lehetőségét, ezáltal az állománybecslés pontossága torzulhat. Megoldást jelenthet a problémára az egyedek hang alapján történő elkülönítése bioakusztikai módszerekkel. Régóta elfogadott tény madarak esetében is, hogy adott faj egyedeinek hangja különbségeket mutat (BAXTER COFFIN, 1928). Egyre több kutatás, tanulmány foglalkozik egyes fajok egyedeinek hang alapján történő azonosításával, a különbségek számszerüsítésével, statisztikai értékelésével. Apácalúd (Branta leucopsis) esetében maga a hívóhang átlagos frekvenciája elegendő volt az egyedek elkülönítéséhez 
(HAUSBERGER et al., 1994). LESSELLS et al. (1995) gyurgyalagok (Merops apiaster) hangját elemezték keresztkorreláció alkalmazásával, egyedi különbségek kimutatására. A két említett esetben azonban egyszerü, egybefüggő, jelentős felharmónikusok nélküli hang elemzését kellett megoldani. Az alkalmazott módszerek azonban nem megfelelőek komplexebb, szünetekkel tagolt szólamok elemzéséhez és leírásához. A legjobb megoldást ilyen esetekben idő- és frekvencia-változók együttes mérése és kombinált alkalmazása jelenti. GALEOTTI \& PAVAN (1991) macskabagoly (Strix aluco), REBBECK et al. (2001) lappantyú (Caprimulgus europaeus) egyedek hangjának különbözőségét igazolta ilyen változók bevezetésével és alkalmazásával. A harisok hang alapján történő egyedi beazonosítására MAY (1994) dolgozott ki metodikát. A módszert továbbfejlesztve, PEAKE et al. (1996) további paraméterek bevonásával 100\%-os biztonságúra növelték az egyes egyedek felismerhetőségét. A módszert hazánkban KENYERES et al. (2000) alkalmazták először.

A haris hímeket párzási időszakban könnyen felismerhetjük jellegzetes hangjukról, amelyet általában napnyugtától hajnalig hallatnak (GLUTZ VON BLOTZHEIM et al., 1994). Percenként átlagosan 33-35 szótagpárt hallatnak, ezek száma egy éjszaka alatt akár a 10000-et is eléri egy madár esetében (PEAKE et al., 1996). A hímek éneke a már említett szótagpárok ismételgetéséből áll. Ezek a szótagok hasonlóak egymáshoz, azonban hosszúságuk és pulzusszámuk eltér egymástól. Az első rendszerint rövidebb, mint a második, és kevesebb pulzust is tartalmaz. Korábbi kutatások az első szótagban átlagosan 13-21 pulzust, a másodikban 16-24 pulzust állapítottak meg. Az egyes pulzusok hossza 3-5ms között, míg a pulzusok közti szünet hossza 4-8ms között alakul (KENYERES et al., 2000).

Vizsgálataink célja egy hansági (Urhanyi-rét) harispopuláció felmérése mellett hangfelvételek készítése, valamint a hangfelvételek feldolgozásának, statisztikai értékelésének segítségével az egyes éneklő hímek egyed szintủ elkülönítése volt. További célkítüzésként fogalmazódott meg a felmért hím egyedek területhüségének vizsgálata a fészkelési perióduson belül.

\section{ANYAG ÉS MÓDSZER}

\section{1. Vizsgálati terület}

A Hanság a Duna és a Rába hordalékkúpja közé záródott medence, teljes területe $447 \mathrm{~km}^{2}$. Felszínét agyag, homok, iszap, tőzeg és kavicsos homok alkotják. A terület negyede ártéri síkság, míg a többi része belvízmentesített alacsonyártér. A csapadékos időszakokban sokszor a negyede is víz alá kerül. Talajainak $80 \%$-a vízhatás alatti lápos réti, lecsapolt és telkesített síkláp, réti és réti öntéstalaj. Vízgazdálkodásukat a nagy mennyiségü lerakódott szerves anyag, valamint a felszín közeli talajvíz határozza meg (DövÉNYI, 2010).

A Hanság eredeti vegetációját nagyobbrészt lápi társulások, ezeken belül is a fátlan társulások alkothatták. A 19. században kezdődő lecsapolások következtében a kistáj átalakult. Az úszólápok, valamint a zsombékosok területe csökkent, a nedves láprétek szintén visszaszorultak (DÖVÉNYI, 2010).

A vizsgálati terület, az Urhanyi-rét $\left(47^{\circ} 43^{\prime} 54.39 " E ́ ; 17^{\circ} 20^{\prime} 5.60^{\prime \prime K}\right)$, egy 100 ha nagyságú egybefüggő kiszáradó láprét (1. ábra). Az északi oldalán a Lébényt Tárnokrétivel összekötő út határolja. Nyugatról az Urhanya-csatorna szegélyezi, keleten és délen fasor övezi. A rét egyes részei időszakosan vízzel borítottak. Domináns növényfajai a gyepes sédbúza (Deschampsia caespitosa), parti sás (Carex riparia), muharsás $(C$. panicea), lápi sás (C. davaliana), borzas sás ( $C$. hirta), barna sás ( $C$. hostiana), nagy szittyó (Juncus subnodulosus), szürke aszat (Cirsium canum), kékperje (Molinia hungarica), réti ecsetpázsit 
(Alopecurus pratensis), réti boglárka (Ranunculus acer), őszi vérfü (Sanguisorba officinalis), réti füzény (Lythrum salicaria), de szép számban találunk ritka, védett fajokat is, mint például a kornistárnics (Gentiana pneumonanthe), lápi nyúlfarkfü (Sesleria uliginosa), nyári tőzike (Leucojum aestivum), hússzínü ujjaskosbor (Dactylorhiza incarnata), mocsári kosbor (Orchis laxiflora) és a buglyos szegfü (Dianthus superbus) (SIPOS 2007).

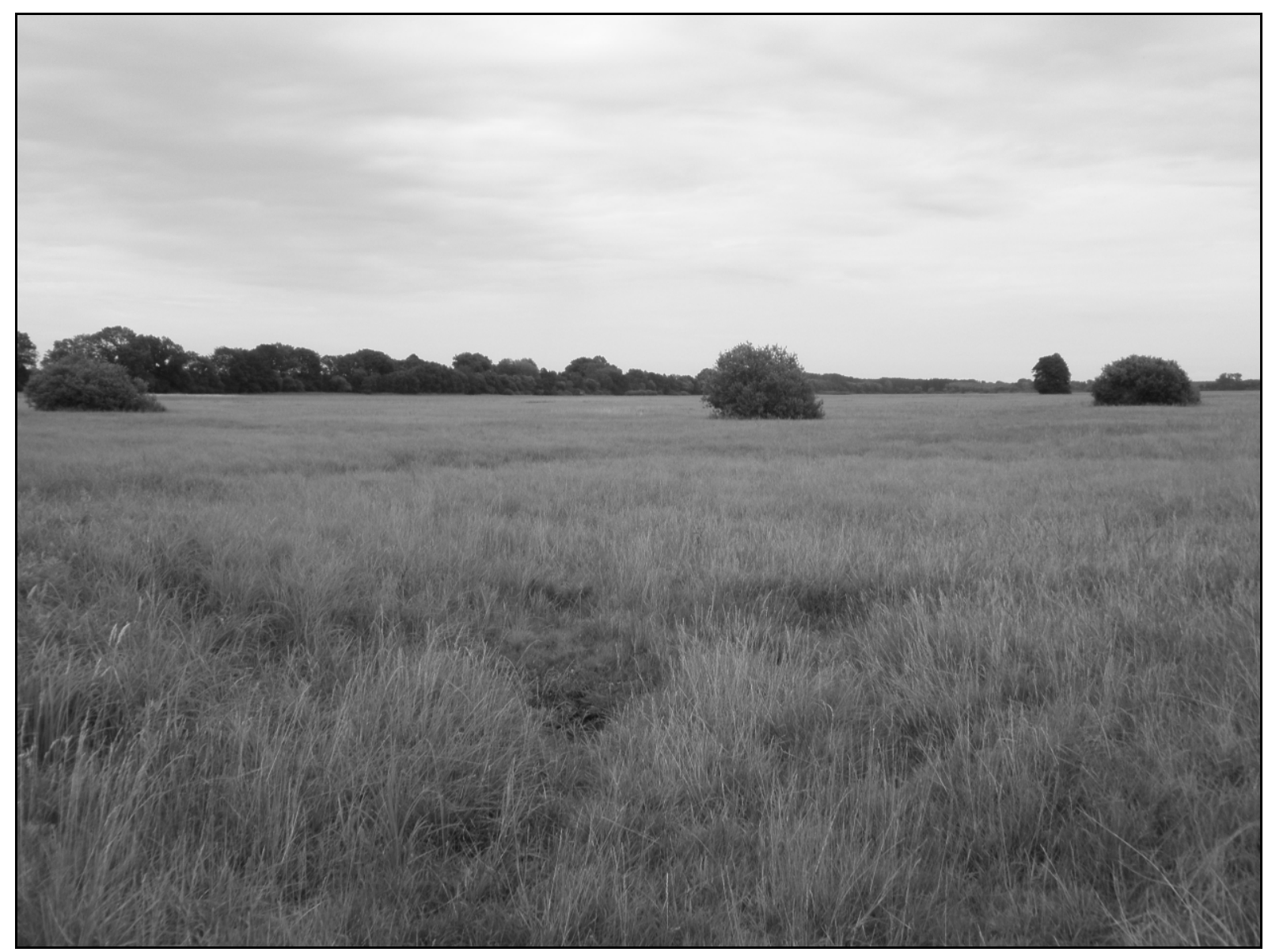

1. ábra. Az Urhanyi-rét (Fotó: Winkler D.)

Figure 1. Urhanyi Meadow (Photo: D. Winkler)

\subsection{Terepi felmérési módszerek}

A terepi felmérések 2010. április-június időszakában történtek, összesen 6 alkalommal, amelyből - elsősorban az időjárási körülmények miatt - megfelelő hangfelfételek készítését csak az alábbi 3 alkalommal tudtuk elvégezni: 2010. április 30; 2010. május 14.; 2010. május 29. A területet szisztematikusan bejárva az éneklö haris hímeket megközelítve hangfelvételek készültek, rögzítve a hangadás helyének GPS koordinátáit.

A felvételek rögzítésére egy Sony MZ-R30 típusú MiniDisc felvevőt, valamint saját készítésü parabola mikrofon rendszert alkalmaztunk AV-JEFE AVL2600 típusú mikrofonnal (2. ábra). A madarakat mintegy 10-15m-re megközelítve összesen 40-40 másodpercnyi hangfelvétel készült minden egyes hím egyed esetében, amely megfelelő pontosságú alapadatot szolgáltatott a későbbi kiértékelésekhez. 


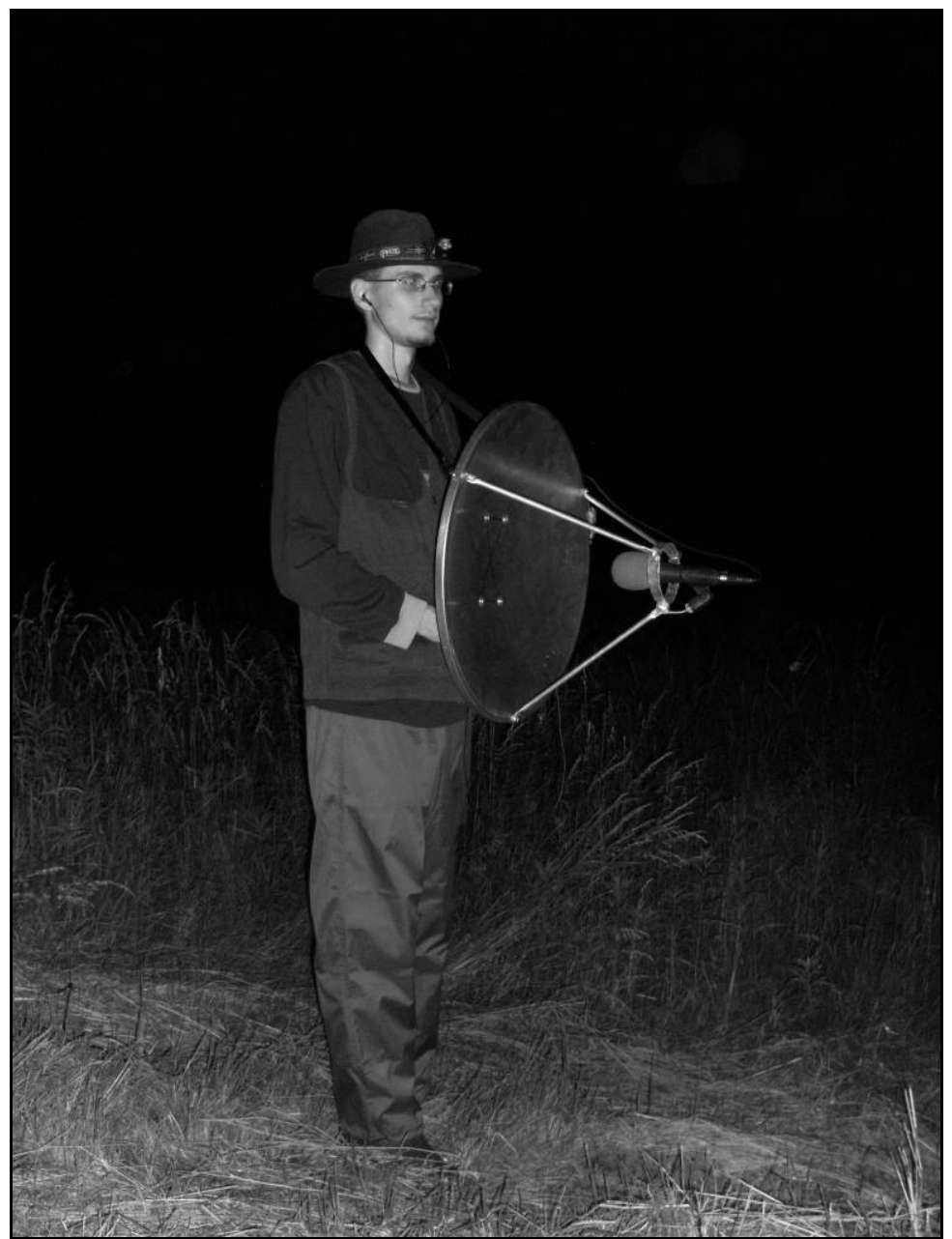

2. ábra: Haris hangfelvételek készítése parabolamikrofonnal (Fotó: Winkler D.)

Figure 2. Recording the Corncrake call using a parabolic microphone (Photo: D. Winkler)

\subsection{A kiértékelés módszerei}

\subsubsection{Hangfizikai változók mérése}

A haris egyedek hang alapján történő azonosításának módszerét MAY (1994) dolgozta ki, öt szótagkarakter diszkriminancia analízise alapján különítve el az egyedeket. Ez az öt karakter egy szótagpáron belül a következő volt: az első szótag hossza, a második szótag hossza, a két szótag közti szünet hossza, az első szótag pulzusszáma, a második szótag pulzusszáma. Ez a módszer 46 vizsgált madár esetében, jack-knife analízis alapján 83\%-os biztonsággal volt alkalmazható. PEAKE et al. (1996) ezeken kívül tíz további változót vezettek be (az első tíz pulzus egyenkénti hossza a szótagpár első szótagjában). Az így összesen 15-re bővült változó számmal már lehetővé vált az egyes egyedek 100\%-os biztonsággal való elkülönítése. KENYERES et al. (2000) a 15 változó mérését madaranként tíz szótagpáron végezték el. Vizsgálataink során ezt a módszert követtük. A méréseket a hullámformán (amplitúdó-idő függvény) végeztuik a Sound Forge Pro 10.0 szoftware segítségével. Minden egyes madárról külön adattábla készült, tíz ismétlésszámmal, amelynek adatrendszerét és az alkalmazott rövidítéseket az 1. táblázat tartalmazza. 
1. táblázat: A haris hangjának mért hangfizikai változói

Table 1: Time- and frequency-based variables of the Corncrake

\begin{tabular}{|c|c|}
\hline $\begin{array}{l}\text { változók } \\
\text { variables }\end{array}$ & $\begin{array}{l}\text { rövidítések } \\
\text { abbreviations }\end{array}$ \\
\hline $\begin{array}{l}\text { elsõ szótag hossza }(\mathrm{sec}) \\
\text { második szótag hossza }(\mathrm{sec}) \\
\text { az első és második szótag közti intervallum hossza (sec) }\end{array}$ & $\begin{array}{c}\text { syl1 } \\
\text { syl2 } \\
\text { int }\end{array}$ \\
\hline $\begin{array}{l}\text { első szótag első pulzusának hossza }(\mathrm{sec}) \\
\text { első szótag második pulzusának hossza }(\mathrm{sec}) \\
\text { első szótag harmadik pulzusának hossza }(\mathrm{sec}) \\
\text { első szótag negyedik pulzusának hossza }(\mathrm{sec}) \\
\text { első szótag ötödik pulzusának hossza }(\mathrm{sec}) \\
\text { első szótag hatodik pulzusának hossza }(\mathrm{sec}) \\
\text { első szótag hetedik pulzusának hossza }(\mathrm{sec}) \\
\text { első szótag nyolcadik pulzusának hossza }(\mathrm{sec}) \\
\text { első szótag kilencedik pulzusának hossza }(\mathrm{sec}) \\
\text { első szótag tizedik pulzusának hossza }(\mathrm{sec})\end{array}$ & $\begin{array}{l}\text { p-pd1 } \\
\text { p-pd2 } \\
\text { p-pd3 } \\
\text { p-pd4 } \\
\text { p-pd5 } \\
\text { p-pd6 } \\
\text { p-pd7 } \\
\text { p-pd8 } \\
\text { p-pd9 } \\
\text { p-pd10 }\end{array}$ \\
\hline $\begin{array}{l}\text { első szótag pulzusszáma }(\mathrm{db}) \\
\text { második szótag pulzusszáma (db) }\end{array}$ & $\begin{array}{l}\text { s1p } \\
\text { s2p }\end{array}$ \\
\hline
\end{tabular}

Az egyes változók hosszának meghatározását a következőképpen végeztük:

- Az első, valamint a második szótag hosszának mérését kurzor segítségével végeztük (3. ábra). A szótag hullámképének első, az alapzajtól markáns eltérést mutató, jól elkülönülő hullámának zérópontja lett a kijelölt szakasz kezdőpontja. A szakasz végét az utolsó impulzus amplitúdó-csillapodásának még látható végpontja jelentette. A szótagpár közötti szünet hossza az első szótag végpontjától a második szótag kezdőpontjáig tart.

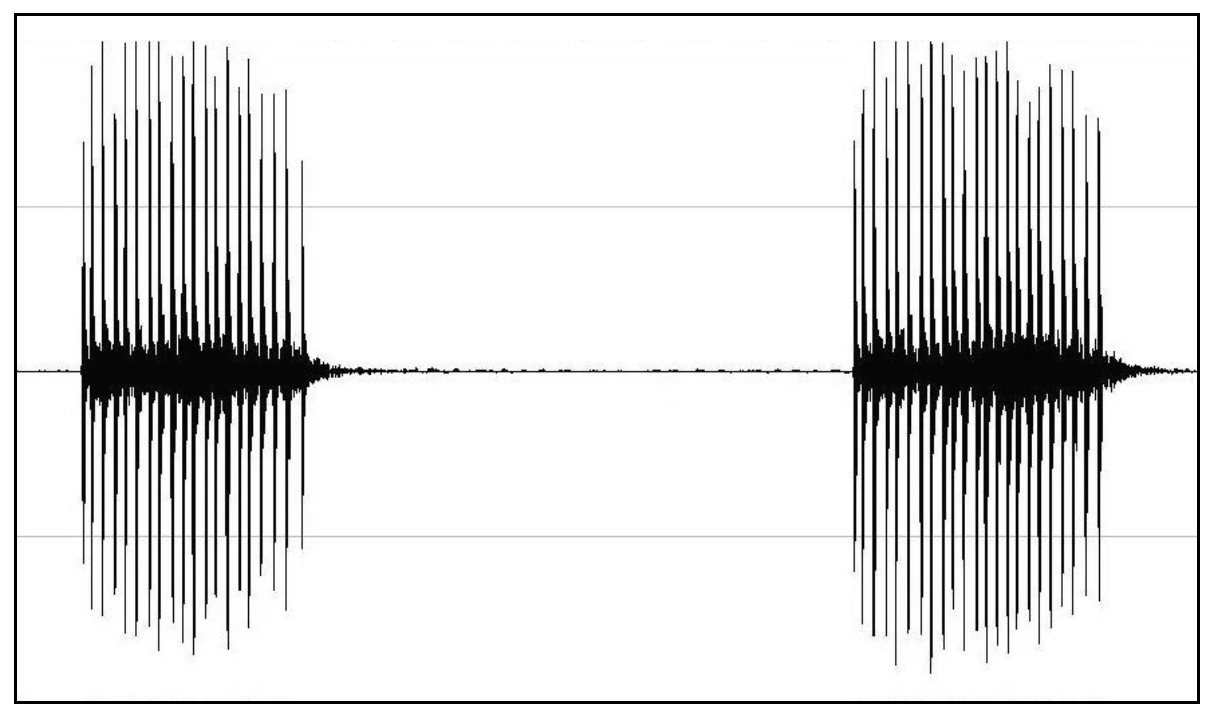

3. ábra: A haris hang szótagpárjának hullámképe (idő - amplitúdó)

Figure 3: Waveform (time v. amplitude) of a complete Corncrake call

- Az első, valamint a második szótag pulzusszámának meghatározását egyszerü leszámolással végeztük (4. ábra). A pulzusok amplitúdó maximuma jelentette az egyes pulzusegységeket. 


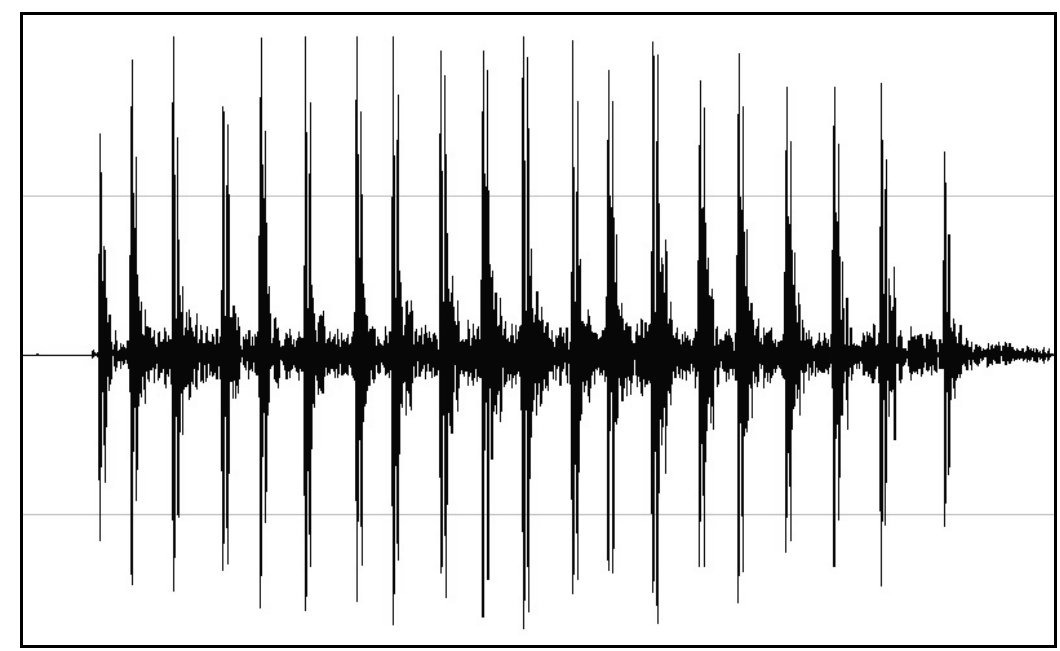

\section{4. ábra: A haris hang első szótagjának hullámképe (idő - amplitúdó)}

Figure 4: Waveform (time v. amplitude) of the first syllable of the Corncrake call

- A szótagpár első szótagjának tíz pulzusát szintén a kurzor segítségével mértük. Itt a pulzus kezdetét a pulzus első, kiugró hullámának zéró db pontja jelentette, míg a pulzus végét a következő pulzus eleje (5. ábra). Így folyamatos a kapcsolat a pulzusok között. Az így meghatározott pulzusegység tartalmazza a pulzus hanghullámát, továbbá a következő pulzus kezdetéig tartó szünetet.

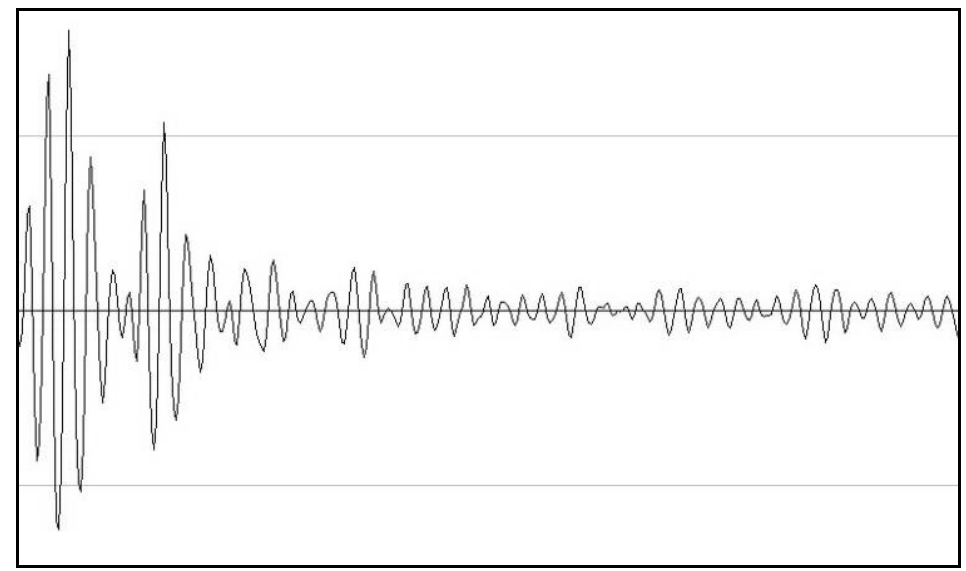

5. ábra: A haris hang egy pulzusának hullámképe

Figure 5: Waveform (time v. amplitude) of a pulse from the Corncrake call

\subsubsection{Statisztikai értékelés}

Az egyes haris egyedekhez tartozó változók statisztikai kiértékelését a korábbi vizsgálatoknál (PEAKE et al., 1996) megadott metodika szerint végeztük. Az elemzésekhez az SPSS 11.5 statisztikai programot használtuk (SPSS 1999).

A haris egyedekhez tarozó mért hangfizikai változók adatmátrixát diszkriminanciaanalízis (DA) segítségével elemeztük. A diszkriminancia-analízis célja, hogy alacsony mérési szintü függő változót magas mérési szintủ független változó (a hang egyes fizikai paraméterei) együttes figyelembevételével magyarázzon. A diszkriminancia-analízis során a magyarázó változókból olyan diszkrimináló függvények jönnek létre, amelyek a legnagyobb különbségeket produkálják a függő változóban a csoportok között. 
A diszkrimináló függvények az egyes harisokhoz a hang 15 változója alapján függvényenként egy-egy értéket rendelnek. Mivel az egyes madarakhoz tartozó változókat 10szeres ismétléssel elemeztük, ezért a függvények egy egyedhez 10 értéket rendelnek hozzá. A program ezekböl az értékekböl csoportközepet képez minden egyes madárhoz. A csoportközepeknek a diszkrimináló függvények által meghatározott koordinátái alapján számoltuk az egyes csoportközepek közötti euklideszi távolságot, a felmért madarak közti valamennyi kombinációs lehetőséget megvizsgálva, páronként. Korábbi vizsgálatok (PEAKE et al., 1996) az euklideszi távolságok mértékét határozták meg az elkülönítés kritériumaként:

1. kritérium tartomány: ha a csoportközepek közötti euklideszi távolság $\leq 4$, úgy a két felvétel 100\%-os bizonyossággal ugyanazon madártól származik.

2. kritérium tartomány: ha a csoportközepek közötti távolság $>4$, de $\leq 8$, az azonosság valószínü, de fennáll a félreazonosítás lehetősége is. Természetesen minél közelebb áll a távolság mértéke az 1. kritérium felső határához (4), annál valószínűbb hogy ugyanazon madárról van szó, bár Peake et al. (1996) 8-hoz közeli euklideszi távolságnál is bizonyítottak azonosságot.

3. kritérium tartomány: ha a csoportközepek közötti euklideszi távolság értéke $>8$, a felvételek két külön madártól származnak.

\section{EREDMÉNYEK ÉS MEGVITATÁS}

\subsection{A harisfelmérés eredményei}

A kezdeti tavaszi terepbejárások alkalmával először április 30-án sikerült észleltünk harisokat a vizsgálati területen, összesen három éneklő hímről készült hangfelvétel (6. ábra).

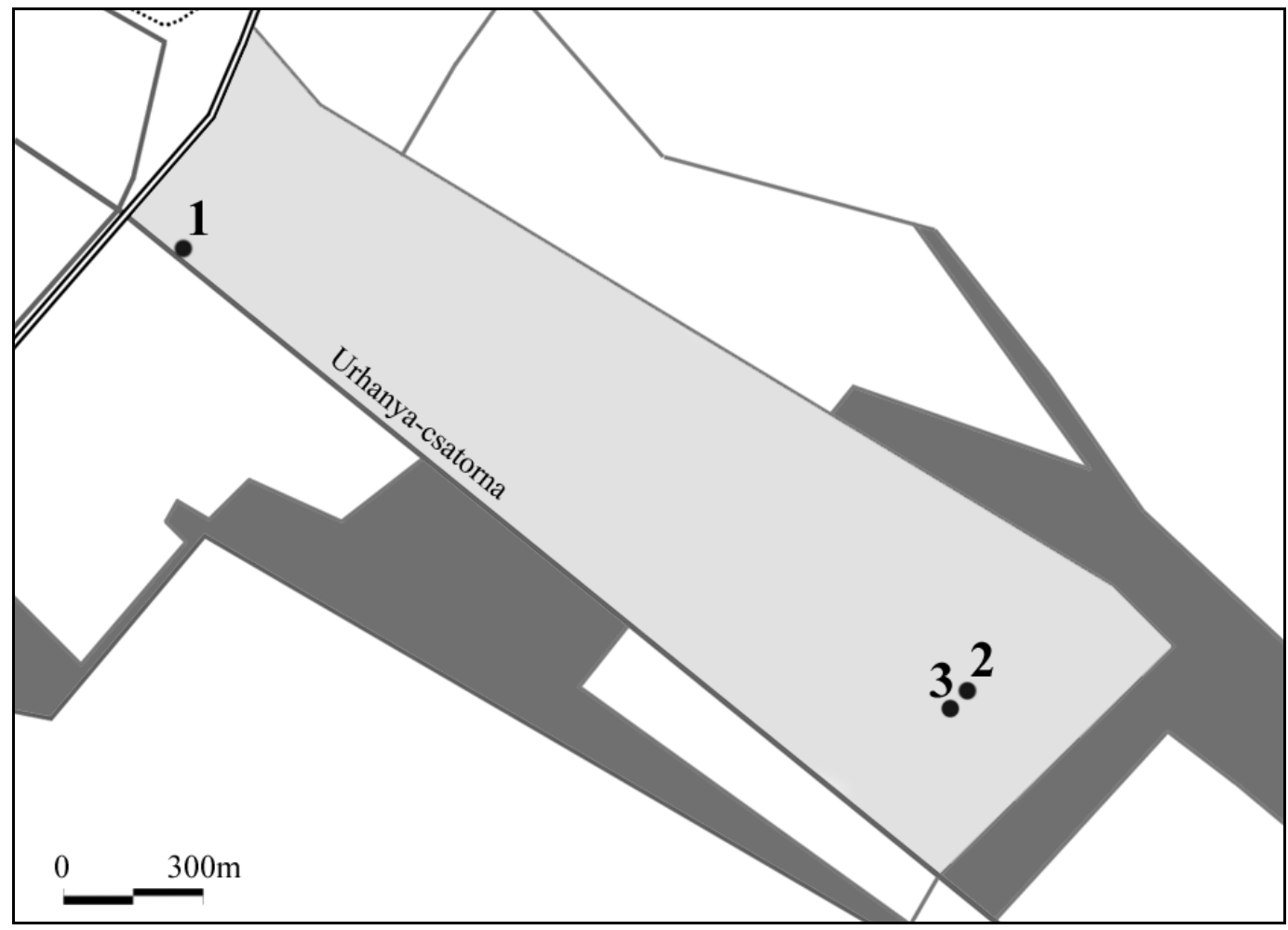

6. ábra: 2010. 04. 30-án rögzített harisok az Urhanyi-réten

Figure 6: Corncrakes recorded in the Urhanyi Meadow (30 April 2010) 
Május 14-én már 8 haris (4-11. sorszám) szólt a területen (7. ábra), míg május 29-én összesen 9 harist (12-20. sorszám) sikerült regisztrálni (8. ábra), illetve ezekről hangfelvételt is készíteni.

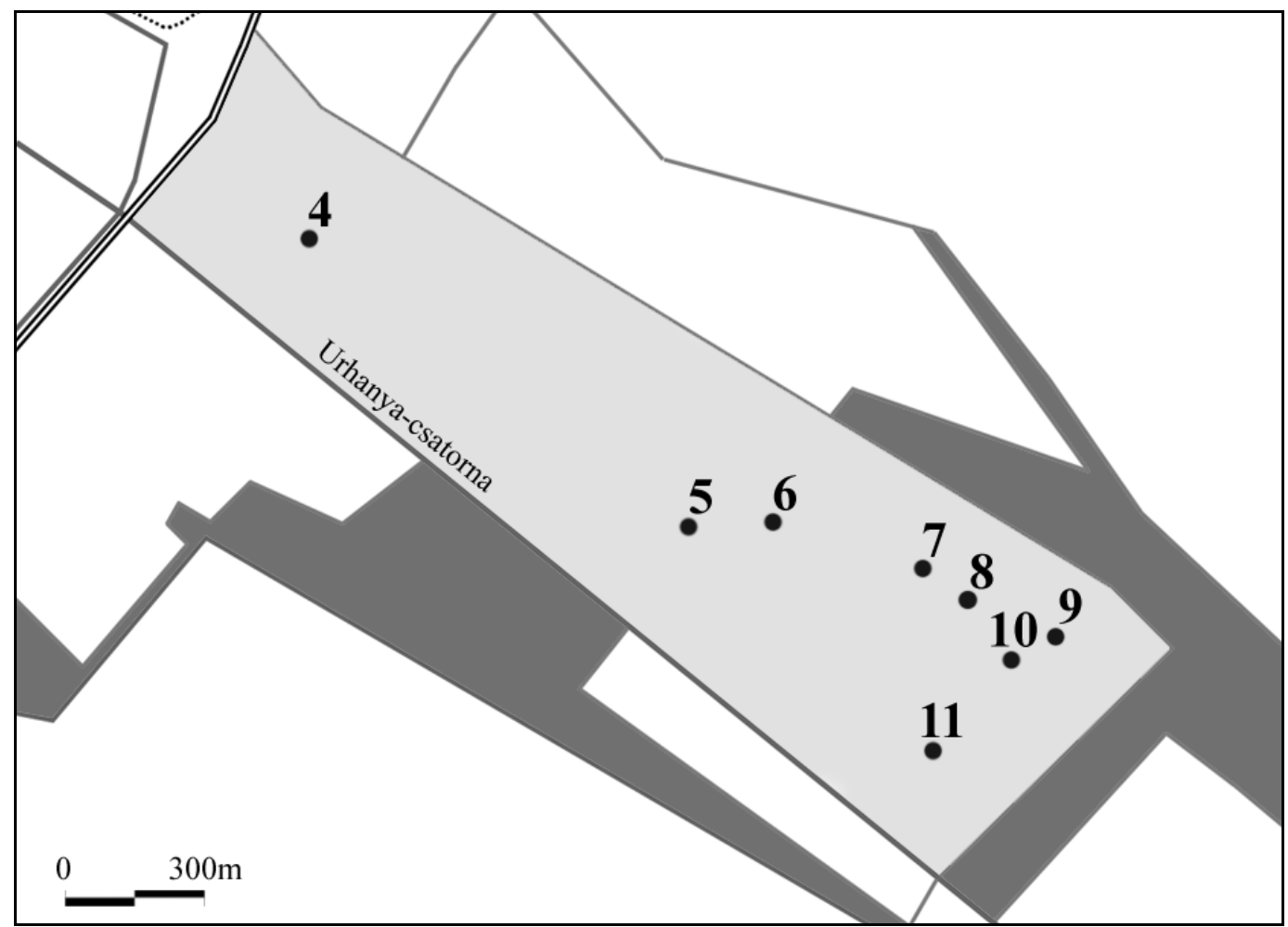

7. ábra: 2010. 05. 14-én rögzített harisok az Urhanyi-réten

Figure 7: Corncrakes recorded in the Urhanyi Meadow (14 May 2010)

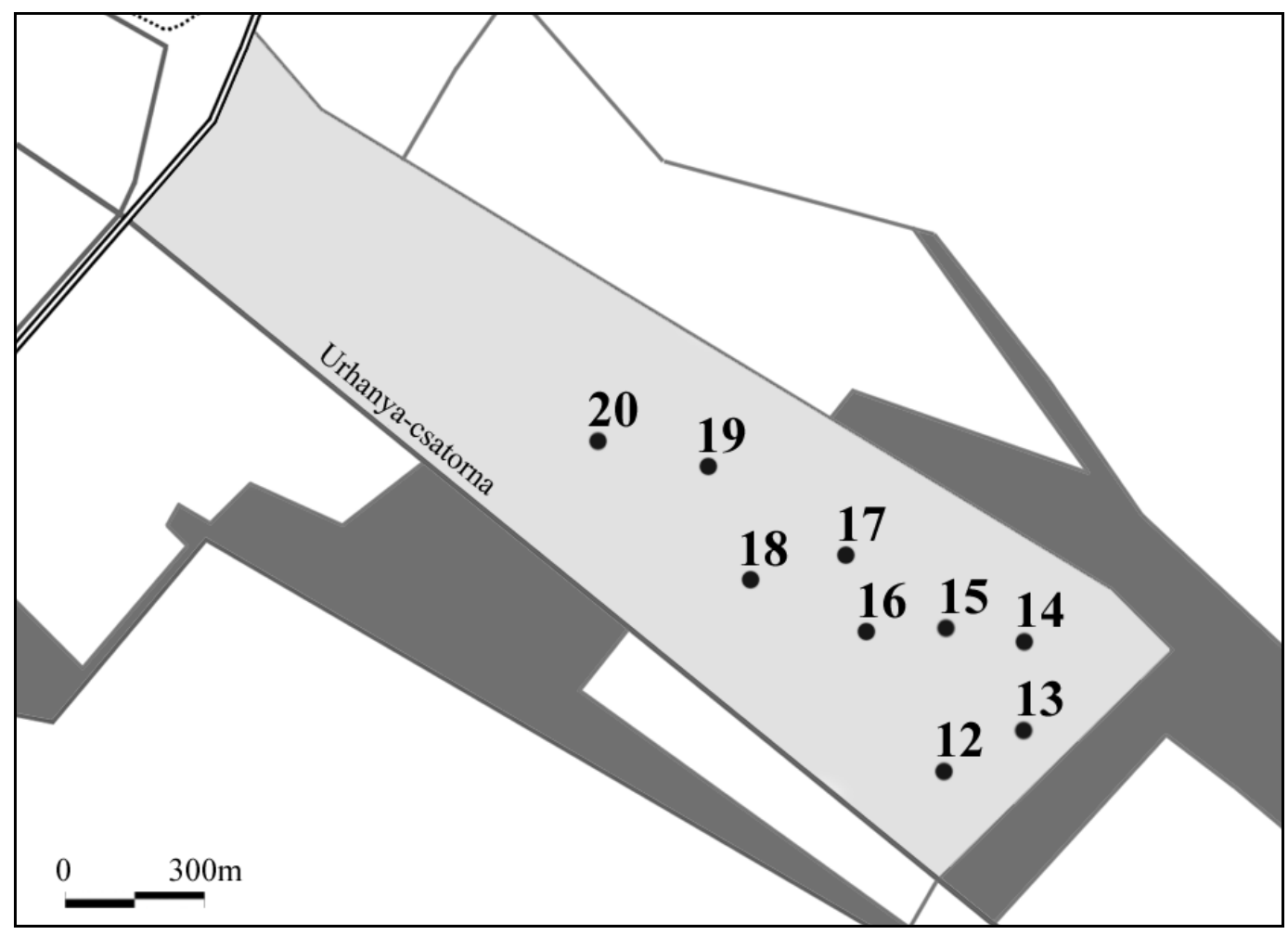

8. ábra: 2010. 05. 29-én rögzített harisok az Urhanyi-réten

Figure 8: Corncrakes recorded in the Urhanyi Meadow (29 May 2010) 


\subsection{Harisok egyedi elkülönítése}

Az egyes felmért haris egyedekhez tartozó, min. 1 perc hosszú hangminták vizsgált hangfizikai változóira kapott átlagértékeket a 2. táblázat tartalmazza.

2. táblázat: A mért hangfizikai változók haris egyedenkénti átlagértékei ( \pm standard hiba, $n=10$ ); a csoportátlagok eltérései (ANOVA egytényezôs varianciaanalízis)

Table 2: Mean values ( \pm standard error, $n=10$ ) of the measured sound variables of individual Corncrake sound samples;comparison of group means (one-way ANOVA)

\begin{tabular}{|c|c|c|c|c|c|c|c|c|c|c|c|c|c|c|c|}
\hline & \multicolumn{15}{|c|}{ Hangfizikai változók / sound variables } \\
\hline & syl1 & int & $y 2$ & $\mathrm{~d} 1$ & $\mathrm{puz}$ & $\mathrm{d} 33$ & $\mathrm{pd} 4$ & p-pd5 & -pd6 & p-pd7 & & & puro & $\mathrm{s} 1 \mathrm{p}$ & $\mathrm{s} 2 \mathrm{p}$ \\
\hline 1 & $\begin{array}{c}0,178 \\
\pm 0,003\end{array}$ & $\begin{array}{c}0,400 \\
\pm 0,003\end{array}$ & \begin{tabular}{|c|}
0,194 \\
$\pm 0,003$
\end{tabular} & & & & & & & & & & & \begin{tabular}{|c|}
18,3 \\
$\pm 0,15$ \\
\end{tabular} & $\begin{array}{c}19,9 \\
\pm 0,10\end{array}$ \\
\hline 2 & $\begin{array}{c}0,180 \\
\pm 0,002 \\
\end{array}$ & $\begin{array}{c}0,455 \\
\pm 0,014\end{array}$ & $\begin{array}{c}0,210 \\
\pm 0,002 \\
\end{array}$ & & & & & & & & & & & \begin{tabular}{|c|}
19,0 \\
$\pm 0,15$ \\
\end{tabular} & $\begin{array}{c}22,7 \\
\pm 0,21 \\
\end{array}$ \\
\hline 3 & & & & & $0009+$ & & & & & & & & & \begin{tabular}{|c|}
18,2 \\
$\pm 0,13$ \\
\end{tabular} & $\begin{array}{c}20,1 \\
\pm 0,10 \\
\end{array}$ \\
\hline 4 & $\begin{array}{c}0,176 \\
\pm 0,002\end{array}$ & $\begin{array}{c}0,407 \\
\pm 0,005\end{array}$ & $\begin{array}{c}0,195 \\
\pm 0,003\end{array}$ & & & & & & & & & & & $\begin{array}{c}18,0 \\
\pm 0,15\end{array}$ & $\begin{array}{c}20,2 \\
\pm 0,20\end{array}$ \\
\hline 5 & $\begin{array}{c}0,203 \\
\pm 0,005\end{array}$ & $\begin{array}{c}0,356 \\
\pm 0,007\end{array}$ & $\begin{array}{c}0,232 \\
\pm 0,004\end{array}$ & & & & & & & & & & & \begin{tabular}{|c|}
20,6 \\
$\pm 0,48$ \\
\end{tabular} & $\begin{array}{c}23,7 \\
\pm 0,37\end{array}$ \\
\hline 6 & $\begin{array}{c}0,190 \\
\pm 0,004\end{array}$ & & $\begin{array}{c}0,209 \\
\pm 0,003\end{array}$ & $0.006+$ & $\begin{array}{l}0,009 \pm \\
0,00005\end{array}$ & & & & & & & & & \begin{tabular}{|c|}
19,7 \\
$\pm 0,45$ \\
\end{tabular} & $\begin{array}{c}22,0 \\
\pm 0,26\end{array}$ \\
\hline 7 & & & & & & & & & & & & & & $\begin{array}{c}18,7 \\
\pm 0,30 \\
\end{array}$ & $\begin{array}{c}22,3 \\
\pm 0,21\end{array}$ \\
\hline 8 & & & & & & & & & & & & & & \begin{tabular}{|c|}
18,3 \\
$\pm 0,21$ \\
\end{tabular} & $\begin{array}{c}20,7 \\
\pm 0,15 \\
\end{array}$ \\
\hline 9 & $\begin{array}{c}0,196 \\
\pm 0,002 \\
\end{array}$ & & & & & & & & & & & & & \begin{tabular}{|c|}
19,2 \\
$\pm 0,25$ \\
\end{tabular} & $\begin{array}{r}21,9 \\
\pm 0,18 \\
\end{array}$ \\
\hline 10 & $\begin{array}{c}0,211 \\
\pm 0,002 \\
\end{array}$ & & & & & & & & & & & & & \begin{tabular}{|c|}
22,5 \\
$\pm 0,17$ \\
\end{tabular} & $\begin{array}{c}24,7 \\
\pm 0,15 \\
\end{array}$ \\
\hline 11 & $\begin{array}{c}0,194 \\
\pm 0,002\end{array}$ & & & & & & & & & & & & & $\begin{array}{c}18,8 \\
\pm 0,13 \\
\end{array}$ & $\begin{array}{r}19,9 \\
\pm 0,10\end{array}$ \\
\hline 12 & \begin{tabular}{|l|l|}
0,181 \\
\end{tabular} & & & & & & & & & & & & & \begin{tabular}{|c|}
19,8 \\
$\pm 0,20$ \\
\end{tabular} & $\begin{array}{c}22,8 \\
\pm 0,20 \\
\end{array}$ \\
\hline 13 & 0,175 & & $\begin{array}{c}0,197 \\
\pm 0,002 \\
\end{array}$ & & & & & & & & & & & \begin{tabular}{|c|}
18,9 \\
$\pm 0,31$ \\
\end{tabular} & $\begin{array}{c}21,4 \\
\pm 0,22 \\
\end{array}$ \\
\hline 14 & & & & & & & & & & & & & & \begin{tabular}{|c|}
17,0 \\
$\pm 0,21$ \\
\end{tabular} & $\begin{array}{c}21,2 \\
\pm 0,13 \\
\end{array}$ \\
\hline 15 & & $\begin{array}{c}0,386 \\
\pm 0,004\end{array}$ & & & & & & & & & & & & \begin{tabular}{|c|}
19,0 \\
$\pm 0,21$ \\
\end{tabular} & $\begin{array}{c}22,5 \\
\pm 0,17\end{array}$ \\
\hline 16 & \begin{tabular}{|c|}
0,167 \\
$\pm 0,002$ \\
\end{tabular} & \begin{tabular}{|c|}
0,378 \\
$\pm 0,003$ \\
\end{tabular} & \begin{tabular}{|c|}
0,179 \\
$\pm 0,000$ \\
\end{tabular} & & & & & & & & & & & \begin{tabular}{|c|}
18,2 \\
$\pm 0,20$ \\
\end{tabular} & $\begin{array}{c}20,1 \\
\pm 0,10 \\
\end{array}$ \\
\hline 17 & \begin{tabular}{|c}
0,192 \\
$\pm 0,002$ \\
\end{tabular} & $\begin{array}{c}0,403 \\
\pm 0,006 \\
\end{array}$ & & & & & & & & & & & & \begin{tabular}{|c|}
19,7 \\
$\pm 0,15$ \\
\end{tabular} & $\begin{array}{c}20,2 \\
\pm 0,13 \\
\end{array}$ \\
\hline 18 & $\begin{array}{c}0,204 \\
\pm 0,003 \\
\end{array}$ & & & & $\begin{array}{l}0,009 \pm \\
0,00004\end{array}$ & & & & & & & & & \begin{tabular}{|c|}
20,5 \\
$\pm 0,31$ \\
\end{tabular} & $\begin{array}{c}23,8 \\
\pm 0,25 \\
\end{array}$ \\
\hline 19 & $\begin{array}{c}0,164 \\
\pm 0,003 \\
\end{array}$ & $\begin{array}{c}0,369 \\
\pm 0,005\end{array}$ & $\begin{array}{c}0,183 \\
\pm 0,002\end{array}$ & & & & & & & & & & & \begin{tabular}{|c|}
18,0 \\
$\pm 0,26$ \\
\end{tabular} & $\begin{array}{c}20,1 \\
\pm 0,18\end{array}$ \\
\hline 20 & $\begin{array}{c}0,169 \\
\pm 0,001\end{array}$ & $\begin{array}{c}0,346 \\
\pm 0,002\end{array}$ & $\begin{array}{c}0,197 \\
\pm 0,002\end{array}$ & & & & & & & & & & & \begin{tabular}{|c|}
17,0 \\
$\pm 0,15$ \\
\end{tabular} & $\begin{array}{r}19,9 \\
\pm 0,18 \\
\end{array}$ \\
\hline$F$ & 27,72 & 39,56 & 47,92 & 85,19 & 186,0 & 74,66 & 99,44 & 327,5 & 362,3 & 284,2 & 95,54 & 110,3 & 139,9 & 26,59 & 62,34 \\
\hline$p$ & 0,01 & 0,01 & 0,01 & 0,01 & 0 & 0,01 & & 0 & & & & & 00 & 0,01 & 0,01 \\
\hline
\end{tabular}

A diszkriminancia-analízis során a magyarázó változókból olyan diszkrimináló függvények jöttek létre, amelyek a legnagyobb különbségeket produkálták a függő változóban a csoportok között. A haris-egyedekhez tartozó hangminták jellemzőinek analízise során kapott modellben összesen tizenöt diszkrimináló függvény jött létre.

A diszkrimináló függvények standardizált együtthatóinak értékeit a 3. táblázat tartalmazza. Érdemes megvizsgálni, hogy az egyes diszkrimináló függvényekben melyek a legnagyobb súllyal szereplő változók. Látható, hogy a legnagyobb magyarázóerővel bíró első 
néhány diszkrimináló függvénynél a PEAKE et al. (1996) által bevezetett változók (első szótag pulzusainak hossza) dominálnak, míg a szótaghosszak, a szótagok közötti intervallum, valamint a pulzusszámok a csekély magyarázóerővel bíró diszkrimináló függvényeknél szerepeltek csak nagyobb súllyal.

\section{3. táblázat: A kanonikus diszkriminancia-függvények standardizált együtthatói}

Table 3: Standardized canonical discriminant function coefficients

\begin{tabular}{|c|c|c|c|c|c|c|c|c|c|c|c|c|c|c|c|}
\hline \multirow{2}{*}{$\begin{array}{c}\text { változó } \\
\text { variable }\end{array}$} & \multicolumn{15}{|c|}{ Diszkrimináló függvény / discriminant function } \\
\hline & 1 & 2 & 3 & 4 & 5 & 6 & 7 & 8 & 9 & 10 & 11 & 12 & 13 & 14 & 15 \\
\hline syl1 & 68 & 4 & 1 & 337 & 0,729 & 0,094 & 9 & $-0,059$ &, 736 & 50 & 313 & $-1,935$ & 31 & $-0,278$ & $-1,780$ \\
\hline syl2 & 0,094 & 0,338 & 101 & 0,024 & $-0,204$ & $-0,060$ & 0,198 & 0,377 & $-0,395$ & $-0,328$ & $-0,033$ & 0,016 & $-0,178$ & $-1,183$ & 0,878 \\
\hline int & 0,064 & $-0,154$ & 0,304 & $-0,448$ & 0,175 & 0,274 & 0,752 & $-0,710$ & 73 & $-0,185$ & 0,205 & $-0,069$ & $-0,012$ & $-0,119$ & 0,019 \\
\hline p-pd1 & 970 & 121 & 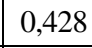 & 169 & $-0,393$ & $-0,667$ & 251 & $-0,472$ & $-0,256$ &, 116 & $-0,006$ & $-0,058$ & $-0,145$ & 0,205 & 0,194 \\
\hline p-pd2 & 359 & 128 & 141 & $-0,187$ & $-0,513$ & $-0,026$ & 392 & 0,240 & $-0,071$ & 522 & $-0,250$ & $-0,009$ & 0,140 & 0,220 & 0,173 \\
\hline p-pd3 & 0,345 & 0,414 & $-0,132$ & $-0,495$ & 0,322 & $-0,411$ & $-0,190$ & $-0,227$ & 0,063 & 0,360 & $-0,114$ & 0,386 & $-0,028$ & $-0,246$ & $-0,231$ \\
\hline p-pd4 & 0,118 & 0,553 & $-0,191$ & 0,308 & $-0,286$ & $-0,064$ & 0,124 & 0,169 & 0,582 & $-0,191$ & $-0,026$ & 0,488 & $-0,157$ & $-0,141$ & $-0,374$ \\
\hline p-pd5 & 0,000 & 6 & 4 & -0 & $-0,080$ & 68 & 8 & 0 & 0,137 & $-0,292$ & 4 & 9 & 0,103 & $-0,023$ & $-0,132$ \\
\hline p-pd6 & $-0,108$ & 0,711 & 0,593 & $-0,111$ & 0,030 & 0,323 & $-0,227$ & 0,184 & $-0,449$ & $-0,340$ & $-0,067$ & 0,289 & 0,374 & 0,290 & 0,045 \\
\hline p-pd7 & 0,594 & 0,203 & 0,524 & 0,049 & 0,532 & 0,447 & $-0,464$ & $-0,178$ & $-0,140$ & $-0,490$ & $-0,689$ & $-0,150$ & 0,305 & 0,362 & 0,206 \\
\hline p-pd8 & 0,533 & 0,144 & 0,912 & 0,053 & 0,592 & 0,044 & $-0,037$ & 0,568 & 0,738 & $-0,203$ & $-0,113$ & $-0,480$ & 0,020 & 0,628 & 0,432 \\
\hline p-pd9 & 0,531 & 0,332 & 0,54 & 0,733 & 1,073 & 0,146 & 0,512 & 0,347 & 0,316 & 0,396 & 0,389 & $-0,215$ & 0,151 & 0,522 & 0,443 \\
\hline p-pd10 & 0,484 & $-0,256$ & 0,705 & 0,783 & 0,504 & $-0,098$ & 0,420 & 0,379 & $-0,155$ & 0,111 & 0,013 & 0,456 & 0,193 & 0,207 & $-0,013$ \\
\hline $\mathrm{s} 1 \mathrm{p}$ & 0,134 & 0,020 & 0,656 & 0,268 & $-0,801$ & $-0,461$ & $-1,059$ & $-0,167$ & 0,941 & 0,608 & $-0,267$ & 1,531 & 1,717 & $-0,102$ & 1,462 \\
\hline $\mathrm{s} 2 \mathrm{p}$ & $-0,031$ & $-0,444$ & 0,576 & $-0,116$ & 0,131 & 0,852 & $-0,061$ & $-0,555$ & 0,334 & 0,606 & 0,084 & 0,110 & $-0,340$ & 0,701 & $-0,737$ \\
\hline
\end{tabular}

A diszkrimináló függvények sajátértékét valamint az értelmezett variancia értékeit a 4. táblázatban foglaljuk össze. A sajátértékek a diszkrimináló függvények által megmagyarázott és megmagyarázatlanul hagyott heterogenitás hányadosai. A táblázatból az is kiolvasható, hogy a teljes megmagyarázott hányadot 100\%-nak tekintve az egyes diszkrimináló függvények hogyan osztoznak ezen a magyarázaton. Látható, hogy a megmagyarázott hányad legnagyobb részben ( 80\%) az első három, leginkább az első szótagpár 5-8. pulzusai által meghatározott függvénynek köszönhető.

\section{4. táblázat: Az értelmezett teljes variancia}

Table 4: Explained total variance

\begin{tabular}{|c|c|c|c|c|}
\hline $\begin{array}{c}\text { Függvény } \\
\text { Function }\end{array}$ & $\begin{array}{c}\text { Sajátérték } \\
\text { Eigenvalue }\end{array}$ & $\begin{array}{c}\text { A variancia \%-a } \\
\text { \% of variance }\end{array}$ & $\begin{array}{c}\text { Kumulatív \% } \\
\text { Cumulative \% }\end{array}$ & $\begin{array}{c}\text { Kanonikus korreláció } \\
\text { Canonical correlation }\end{array}$ \\
\hline 1 & 91,035 & 49,1 & 49,1 & 0,995 \\
\hline 2 & 29,461 & 15,9 & 65,0 & 0,983 \\
\hline 3 & 25,933 & 14,0 & 79,0 & 0,981 \\
\hline 4 & 12,658 & 6,8 & 85,8 & 0,963 \\
\hline 5 & 6,607 & 3,6 & 89,3 & 0,932 \\
\hline 6 & 5,825 & 3,1 & 92,5 & 0,924 \\
\hline 7 & 4,452 & 2,4 & 94,9 & 0,904 \\
\hline 8 & 2,848 & 1,5 & 96,4 & 0,860 \\
\hline 9 & 2,508 & 1,4 & 97,8 & 0,846 \\
\hline 10 & 2,094 & 1,1 & 98,9 & 0,823 \\
\hline 11 & 0,785 & 0,4 & 99,3 & 0,663 \\
\hline 12 & 0,596 & 0,3 & 99,6 & 0,611 \\
\hline 13 & 0,437 & 0,2 & 99,9 & 0,551 \\
\hline 14 & 0,213 & 0,1 & 100,0 & 0,419 \\
\hline 15 & 0,011 & 0,0 & 100,0 & 0,107 \\
\hline
\end{tabular}


Érdemes ellenőrizni, hogy a program tényleg olyan diszkrimináló-függvényeket hozott létre, amelyek értékei a lehető legnagyobb mértékben eltérnek az egyes típusok között. Ezt az 5. táblázatban látható Wilks' Lambda értékek és a megfelelő szignifikanciák segítségével vizsgálhatjuk.

\section{5. táblázat: Diszkrimináló függvények tesztje}

Table 5: Tests of the discriminal functions

\begin{tabular}{|c|c|c|c|c|}
\hline $\begin{array}{c}\text { Függvény teszt } \\
\text { Test of Function }\end{array}$ & Wilks' Lambda & $\begin{array}{c}\text { Chi-négyzet } \\
\text { Chi-square }\end{array}$ & df & Sig. \\
\hline 1-töl 15.-ig & 0,000 & 4508,126 & 285 & 0,000 \\
\hline 2-től1 15-ig & 0,000 & 3687,351 & 252 & 0,000 \\
\hline 3-tól 15-ig & 0,000 & 3067,267 & 221 & 0,000 \\
\hline 4-től 15-ig & 0,000 & 2469,526 & 192 & 0,000 \\
\hline 5-töl 15-ig & 0,000 & 1995,032 & 165 & 0,000 \\
\hline 6-tól 15-ig & 0,000 & 1626,747 & 140 & 0,000 \\
\hline 7-től1 15-ig & 0,001 & 1278,150 & 117 & 0,000 \\
\hline 8-tól 15-ig & 0,005 & 970,334 & 96 & 0,000 \\
\hline 9-től 15-ig & 0,018 & 725,742 & 77 & 0,000 \\
\hline 10-től 15-ig & 0,064 & 497,954 & 60 & 0,000 \\
\hline 11-től 15-ig & 0,199 & 292,955 & 45 & 0,000 \\
\hline 12-től 15-ig & 0,355 & 187,819 & 32 & 0,000 \\
\hline 13-tól 15-ig & 0,567 & 102,932 & 21 & 0,000 \\
\hline 14-től 15-ig & 0,815 & 37,132 & 12 & 0,000 \\
\hline 15 & 0,989 & 2,075 & 5 & 0,839 \\
\hline
\end{tabular}

Az első teszt (1-től 15-ig) mind a tizenöt diszkrimináló függvény által együttesen magyarázat nélkül hagyott négyzetösszeget a függvények teljes heterogenitását jelentő négyzetösszegéhez viszonyítja. Az eredmények azt mutatják, hogy a tizenöt függvény együtt szignifikáns különbséget produkál a húsz függő változó (felmért haris egyedek) között. A következő teszt (2-től 15-ig) azt vizsgálja, hogy az első függvényt elhagyva a modellből a többi függvény a teljes heterogenitás mekkora részét hagyja magyarázat nélkül. Fokozatosan kihagyva a többi függvényt is a tesztekből azt az eredményt kapjuk, hogy az első tizennégy variáció szignifikáns különbséget ad a jellemzők között. A Wilks’ Lambda értékei a diszkrimináló erő mértékét fejezik ki. Minél kisebb a kapott érték, annál nagyobb a diszkrimináló erő. Látható, hogy az egyes függvényeket kihagyva fokozatosan - számottevően a hetedik esettől kezdődően - csökken a diszkrimináló erö.

A diszkriminancia-analízis a bemenő adatokat 20 csoportba sorolta, amely mindegyike egy-egy madarat képvisel. A helyesen besorolt esetek aránya 98,0\%-nak adódott. A 9. ábra ezt a 20 csoportot szemlélteti az első két diszkrimináló függvény által meghatározott topológiai térben. Bár több madárhoz tartozó csoportközepek is közel esnek egymáshoz ebben a kétdimenziós térben, egzakt elkülönítést az euklideszi távolságok adhatnak (6. táblázat), figyelembe véve az összes diszkrimináló függvény által meghatározott többdimenziós teret.

A madárpáronkénti euklideszi távolságokat figyelembe véve, azokat az ismertetett kritériumrendszerrel összevetve elmondható, hogy az 1. kritérium (euklideszi távolság <4) nem teljesült egyetlen esetben sem, ami azt jelenti, hogy 100\%-os biztonsággal egyetlen egyedet sem mértünk fel kétszer a vizsgálatok során.

A 2. kritériumnak (euklideszi távolság értéke 4 és 8 közé esik) összesen négy párosítás felelt meg (ezeket a táblázatban kiemelve jelöltük). 


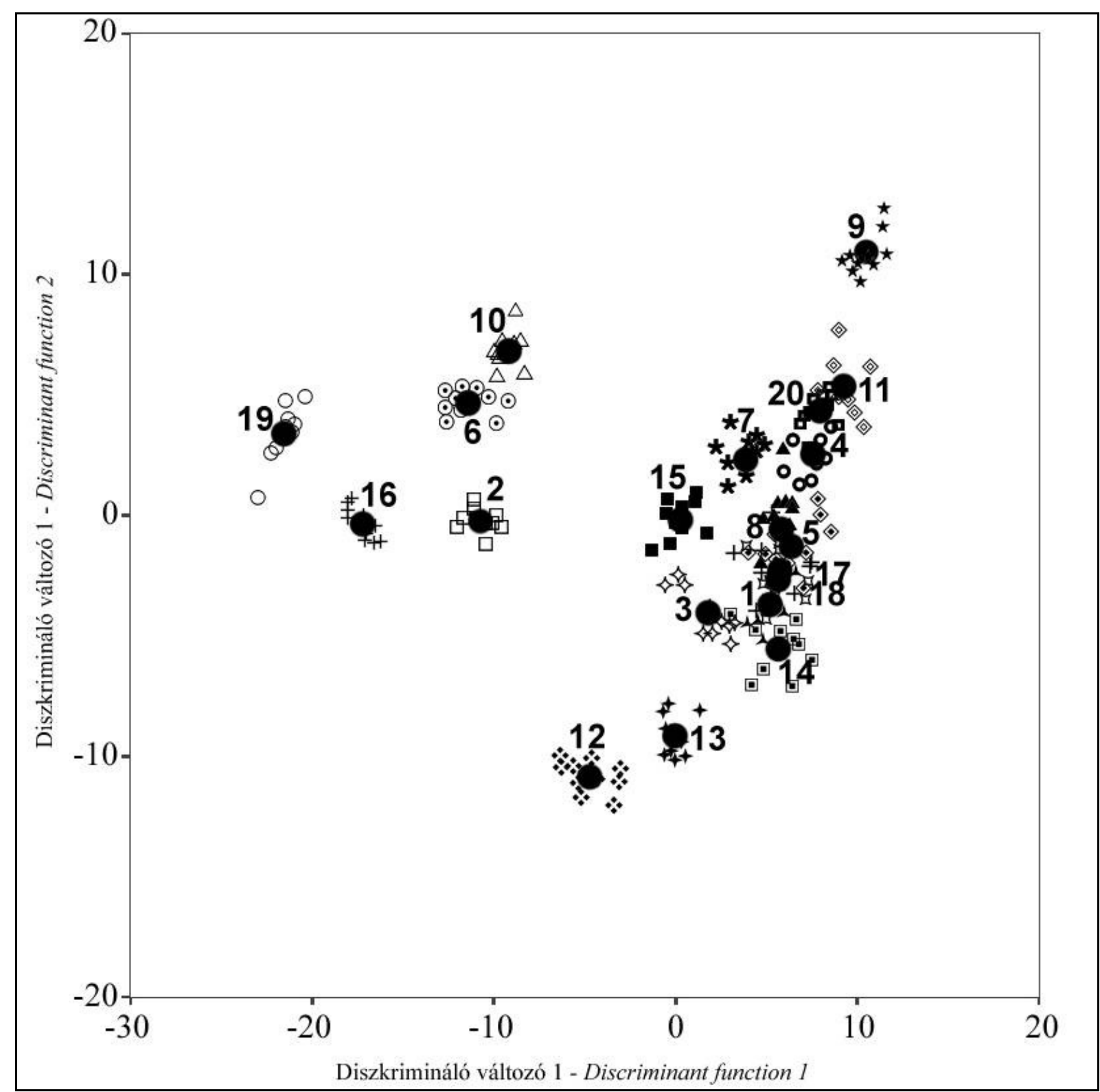

\section{9. ábra: A kanonikus változók alapján csoportosított haris egyedek diszkriminancia topológiája (• csoportközép)}

Figure 9: Topology of Corncrake individuals grouped by canonical variables ( $\bullet$ group centroids)

A 2. kritériumnak megfelelő értékeknél nagy eséllyel állítható, hogy egyazon egyedtől származnak a hangfelvételek, bár néhány esetben ennek az ellenkezője is beigazolódott (PEAKE et al., 1996). Ezeket az eseteket éppen ezért fenntartással kell kezelni. A dürgő hímek helyének pontos ismeretével (GPS koordináták rögzítése) azonban a legtöbb esetben mérlegelhető és eldönthető az egyedi azonosság (10. ábra). Ebböl a tartományból a legnagyobb euklideszi távolság érték $(7,3)$ két, azonos napon felvett hang (4. és 8. sz. madár 2010. május 14-én) adatainak elemzésekor adódott. Mivel ez az érték közel van a 3. kritérium 8-as alsó értékhatárához, valószínüsíthető, hogy a felvett hangok két különböző egyedtől származnak. Ezt látszik alátámasztani a két madár dürgési helye közt mért meglehetősen nagy távolság is ( 1,6 km). A dürgő hímek ugyanis ragaszkodnak a dürgőhelyükhöz, agresszíven védelmezik azt (SCHÄFFER \& MÜNCH, 1993), és attól nem távolodnak el éjszaka (HUDSON et al., 1990; Stowe \& Hudson, 1991; GrabovsKy 1993; TYLER \& GREEN 1996; SKLÍBA \& FuCHS 2004). 


\section{6. táblázat: A csoportközepek közötti euklideszi távolságok}

Table 6: Euclidean distance between group centroids

\begin{tabular}{|c|c|c|c|c|c|c|c|c|c|c|c|c|c|c|c|c|c|c|c|}
\hline $\begin{array}{c}\text { Haris egyed } \\
\text { Corncrake ind. }\end{array}$ & $\mathbf{1}$ & $\mathbf{2}$ & $\mathbf{3}$ & $\mathbf{4}$ & $\mathbf{5}$ & $\mathbf{6}$ & $\mathbf{7}$ & $\mathbf{8}$ & $\mathbf{9}$ & $\mathbf{1 0}$ & $\mathbf{1 1}$ & $\mathbf{1 2}$ & $\mathbf{1 3}$ & $\mathbf{1 4}$ & $\mathbf{1 5}$ & $\mathbf{1 6}$ & $\mathbf{1 7}$ & $\mathbf{1 8}$ & $\mathbf{1 9}$ \\
\hline $\mathbf{2}$ & 18,7 & & & & & & & & & & & & & & & & & & \\
\hline $\mathbf{3}$ & 9,3 & 17,7 & & & & & & & & & & & & & & & & & \\
\hline $\mathbf{4}$ & 11,0 & 21,7 & 14,4 & & & & & & & & & & & & & & & & \\
\hline $\mathbf{5}$ & 11,6 & 20,0 & 14,8 & 15,3 & & & & & & & & & & & & & & & \\
\hline $\mathbf{6}$ & 19,8 & 11,5 & 17,7 & 21,4 & 21,4 & & & & & & & & & & & & & & \\
\hline $\mathbf{7}$ & 11,0 & 16,9 & 14,9 & 13,6 & 12,2 & 18,0 & & & & & & & & & & & & & \\
\hline $\mathbf{8}$ & 9,3 & 21,2 & 11,4 & $\mathbf{7 , 3}$ & 16,3 & 19,9 & 14,5 & & & & & & & & & & & & \\
\hline $\mathbf{9}$ & 17,3 & 26,2 & 19,5 & 13,3 & 16,0 & 23,9 & 15,5 & 15,9 & & & & & & & & & & & \\
\hline $\mathbf{1 0}$ & 22,3 & 13,7 & 19,8 & 24,2 & 19,4 & 12,6 & 18,6 & 23,7 & 22,5 & & & & & & & & & & \\
\hline $\mathbf{1 1}$ & 12,9 & 23,2 & 13,1 & 10,7 & 15,0 & 21,9 & 13,6 & 11,7 & 9,2 & 22,4 & & & & & & & & & \\
\hline $\mathbf{1 2}$ & 14,9 & 15,9 & 14,2 & 21,0 & 18,6 & 18,6 & 17,7 & 17,8 & 27,1 & 21,1 & 22,4 & & & & & & & & \\
\hline $\mathbf{1 3}$ & 14,4 & 19,8 & 11,5 & 17,7 & 16,8 & 20,8 & 20,1 & 15,1 & 23,5 & 22,6 & 18,8 & 12,3 & & & & & & & \\
\hline $\mathbf{1 4}$ & $\mathbf{6 , 1}$ & 19,8 & 10,3 & 11,2 & 11,6 & 20,5 & 13,5 & 8,7 & 18,4 & 23,6 & 14,2 & 14,6 & 12,0 & & & & & & \\
\hline $\mathbf{1 5}$ & 10,8 & 13,6 & 13,6 & 15,4 & 12,5 & 15,3 & $\mathbf{5 , 1}$ & 15,3 & 18,4 & 17,1 & 15,6 & 14,2 & 17,8 & 13,0 & & & & & \\
\hline $\mathbf{1 6}$ & 23,3 & 12,4 & 21,7 & 26,6 & 27,2 & 10,7 & 23,7 & 24,4 & 30,9 & 18,1 & 28,4 & 18,2 & 22,6 & 24,2 & 20,1 & & & & \\
\hline $\mathbf{1 7}$ & 9,0 & 20,1 & 11,2 & 15,3 & 9,9 & 21,0 & 11,6 & 15,3 & 17,6 & 20,2 & 14,7 & 17,1 & 17,9 & 12,1 & 12,0 & 25,3 & & & \\
\hline $\mathbf{1 8}$ & 13,1 & 20,3 & 15,4 & 18,3 & $\mathbf{4 , 1}$ & 22,2 & 13,9 & 18,6 & 18,3 & 19,4 & 17,0 & 18,5 & 17,6 & 13,2 & 13,7 & 27,3 & 9,9 & & \\
\hline $\mathbf{1 9}$ & 28,9 & 17,9 & 26,3 & 30,1 & 30,9 & 13,7 & 29,4 & 29,1 & 33,7 & 20,0 & 32,3 & 24,7 & 26,4 & 29,4 & 26,4 & 11,7 & 30,3 & 31,5 & \\
\hline $\mathbf{2 0}$ & 11,7 & 23,4 & 15,4 & 8,9 & 16,5 & 21,6 & 14,5 & 9,3 & 11,3 & 23,9 & 11,2 & 22,0 & 19,6 & 12,4 & 16,1 & 26,0 & 14,9 & 18,5 & 30,9 \\
\hline
\end{tabular}

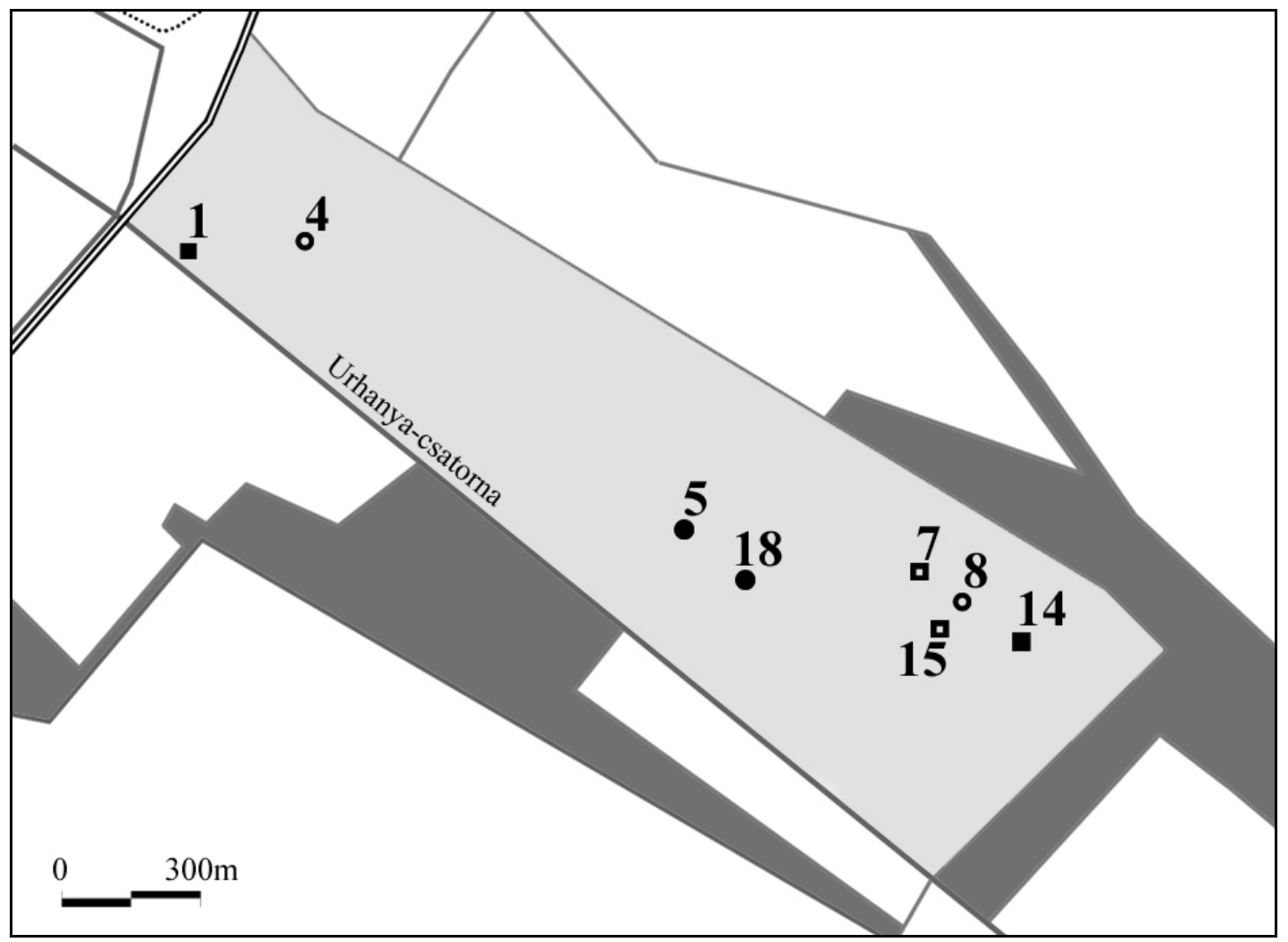

10. ábra: Az újra azonosított haris egyedek (azonos szimbólummal jelölve) az Urhanyi-réten Figure 10: Corncrakes re-identified (marked with same symbols) in the Urhanyi Meadow 
A további három esetben különböző napokon rögzített felvételpárok mutattak nagy hasonlóságot. Az euklideszi távolság alacsonyabb értékei alapján feltételezhetjük, hogy azonos hímeket sikerült beazonosítanunk a különböző felvételi időpontokban. Az 5. és 18. sz. madár, valamint a 7. és 15. sz. madár esetében az euklideszi távolság 4,1-nek, illetve 5,1-nek adódott. Mivel ezek az értékek az 1. kritérium (biztos azonosság) felső határértékéhez nagyon közel esnek, valamint a dürgési helyek is közel azonos ponton voltak a két időpontban, ezek alapján nagy biztonsággal kijelenthető, hogy május 14-én és május 29-én ugyanazt a két madarat sikerült detektálnunk a területen. Az 1. és 14. sz. madár esetében az euklideszi távolság $(6,1)$ a 2. kritériumtartomány középértéke körül van. Bár a dürgési helyek egymástól való nagyobb távolsága $(\sim 1,8 \mathrm{~km})$ arra engedhet következtetni, hogy nem feltétlen azonos madártól származnak a hangok, a két felvétel (április 30 és május 29) között eltelt idö (közel egy hónap) nem zárja ki annak a lehetőségét sem, hogy a madár kedvezőbb dürgőhelyet választott az eltelt idő alatt.

\section{KONKLÚZIÓ}

Az elemzéseket összegezve megállapítható, hogy az ismertetett módszerrel feltehetően három egyedet sikerült újra detektálni különböző felmérési időpontban. Így a vizsgálati időszakban rögzített 20 haris hang összesen 17 különböző egyedet képvisel. Az eredmények rávilágítanak arra, hogy az általánosan alkalmazott, fészkelési időszakban több alkalommal végzett, hang alapján történő egyedszámbecslés nem mindig ad egzakt eredményt. Az alkalmankénti dürgő hímek maximális értékét alapul véve 9, egy évesnél idősebb hím jelenlétével számolhatnánk, ami jóval kevesebb a megálapított 17-nél. Természetesen figyelembe kell venni, hogy a teljes fészkelési időszakban - de különösen a korán érkező madarak esetében - közeli-távolabbi elmozgások, elvándorlások is lehetnek. Ezt igazolja, hogy az első felmérés során rögzített madarak közül csak egy, míg a második alkalommal detektáltak közül kettőt sikerült kisebbnagyobb biztonsággal azonosítanunk későbbi felvételi időpontokban.

\section{IRODALOMJEGYZÉK}

BAXTER Coffin, L.V. (1928): Individuality in Bird Song. The Wilson Bulletin 40(2): 95-99.

DöVÉNYI Z. szerk. (2010): Magyarország kistájainak katasztere. MTA Földrajzi Kutatóintézet. Budapest, 876 pp.

Galeotti, P. \& PAvan, G. (1991): Individual recognition of male Tawny Owls (Strix aluco) using spectrograms of their territorial calls. Ethology Ecology and Evolution 3: 113-126. http://dx.doi.org/10.1080/08927014.1991.9525378

GlutZ VON BlotZheim, U. N., BAUER, K. M., \& Bezzel, E. (1994): Handbuch der Vögel Mitteleuropas. 2. durchges. AULA-Verlag GmbH, Wiesbaden. Band 5. 705 pp.

GRABOVSKY, V.I. (1993): Spatial distribution and spacing behaviour of males in a Russian corncrake population. Gibier Faune Sauvage 10: 259-279.

HAusberger, M., Richard, J. P., BLACK, J. M. \& QURIS, R. (1994): A quantitative analysis of individuality in Barnacle Goose loud calls. Bioacoustics 5: 247-260. http://dx.doi.org/10.1080/09524622.1994.9753255

HORVÁTH R. (2000): Haris. In HARASZTHY L. szerk.: Magyarország madarai. Mezőgazda Kiadó, Budapest. 114-115. 
Hudson, A. V., Stowe, T.J. \& Aspinall, S. J. (1990): Status and distribution of Corncrakes in Britain. British Birds 83: 173-186.

KENYERES A., WeTTSTEIN, W. \& SZÉP T. (2000): Haris egyedek felismerése hangelemzés alapján. Ornis Hungarica 10: 65-70.

Lessells, C. M., Rowe, C. L. \& MCGREGor, P. K. (1995): Individual and sex differences in the provisioning calls of European bee-eaters. Anim. Behav. 49: 244-247. http://dx.doi.org/10.1016/0003-3472(95)80174-X

MAY, L. (1994): Individually distinctive Corncrake (Crex crex) calls: A pilot study. Bioacoustics 6: 25-32. http://dx.doi.org/10.1080/09524622.1994.9753269

MME NOMENCLATOR BIZOTTSÁG (2008): Magyarország madarainak névjegyzéke. Nomenclator Avium Hungariae. Magyar Madártani és Természetvédelmi Egyesület, Budapest, 278 pp.

NÉMETH T.M. (2012): A haris (Crex crex) állományvizsgálata az Örségben. Magyar Apróvad Közlemények 11: 49-58.

Peake, T.M., McGregor, P.K., Smith, K.W., Tyler, G., Gilbert, G. \& Green, R. E. (1998): Individuality in Corncrake (Crex crex) vocalizations. Ibis 140: 120-127. http://dx.doi.org/10.1111/j.1474-919X.1998.tb04548.x

Rebbeck, M., Corrick, R., Eaglestone, B. \& Stainton, C. (2001): Recognition of individual European Nightjars (Caprimulgus europaeus) from their song. Ibis 143: 468-475. http://dx.doi.org/10.1111/j.1474-919X.2001.tb04948.x

SCHÄFFER, N. \& MÜNCH, S. (1993): Untersuchungen zur Habitatwahl und Brutbiologie des Wachtelkönigs Crex crex im Murnauer Moos (Oberbayern). Die Vogelwelt 114: 55-72.

SIPOS S. T.-NÉ (2007): A haris élőhelyválasztása és a 2002-2006 közötti állomány változása az ÉszakHanságban. Szakdolgozat. Debreceni Egyetem, 86 pp.

SKLÍBA, J. \& FUCHS, R. (2004): Male corncrakes (Crex crex) extend their home ranges by visiting the territories of neighbouring males: Capsule radiotracked male corncrake often intruded on the territories of neighbouring males. Bird Study 51(2): 113-118.

http://dx.doi.org/10.1080/00063650409461342

SPSS (1999): SPSS Base 10.0. SPSS Incorporation, Chicago.

StOwE, T. J. \& HudSON, A.V. (1991): Corncrakes outside the breeding grounds, and ideas for a Conservation Strategy. Vogelwelt 112(1-2): 103-107.

SZÉP T. (1991): The present and historical situation of the Corncrake in Hungary. Die Vogelwelt 112: $45-48$.

TATAI S. (2009): A haris (Crex crex) védelme Győr-Moson-Sopron megyében. Szélkiáltó 14: 25.

TYLER, G.A. \& GREEN R.E. (1996): The incidence of nocturnal song by male Corncrakes (Crex crex) is reduced during pairing. Bird Study 43: 214-119.

http://dx.doi.org/10.1080/00063659609461013 